\title{
The Effective Insecticidal Activity of the two Extracts Ethyl Acetate and Hexan of Trichilia gilgiana against Sitophilus zeamaïs
}

\author{
Aba-Toumnou Lucie ${ }^{1,2,3}$, Wango Solange Patricia ${ }^{3}$, Kosh-Komba Ephrem ${ }^{1,3}$, Namkosséréna Salomon ${ }^{4}$, \\ Bolevane-Ouatinam Serge Florent ${ }^{3}$, Lakouèténé Didier Ponel-Béranger ${ }^{1,2}$, SEMBALLA Silla ${ }^{1}$, \\ YONGO Olga-Diane ${ }^{5,6}$, SYSSA-MAGALE Jean-Laurent ${ }^{6}$, Dogo SECK ${ }^{2} \&$ Sembène Mbacké $^{7}$ \\ ${ }^{1}$ Laboratory of Biological and Agronomical Sciences for Development, Bangui, Central African Republic \\ ${ }^{2}$ Regional Centre for Ecotoxicology Studies and Chemical Environment Security (CERES-Locustox), Dakar 3300, \\ Senegal \\ ${ }^{3}$ Laboratory of Applied Animal Biology and Biodiversity, University of Bangui, Bangui, Central African Republic \\ ${ }^{4}$ Regional Pole of Applied Research to Development Farming Systems in Central Africa (PRASAC), Bangui, \\ Central Africa Republic \\ ${ }^{5}$ Center of studies in traditional medicine and pharmacopoeia, Bangui, Central African Republic \\ ${ }^{6}$ Faculty of Sciences, University of Bangui, Central African Republic \\ ${ }^{7}$ Faculty of Sciences, Cheikh Anta Diop University, Dakar 5005, Senegal \\ Correspondence: Aba-Toumnou Lucie, Laboratory of Biological and Agronomical Sciences for Development, \\ Bangui, Central African Republic. E-mail: toumnou@yahoo.fr
}

Received: December 13, 2015 Accepted: December 24, 2015 Online Published: January 12, 2016

doi:10.5539/ijb.v8n2p23

URL: http://dx.doi.org/10.5539/ijb.v8n2p23

\begin{abstract}
Post-harvest losses are recognized to be one of the critical constraints upon food security among farmers of poor resource in Africa.The use of botanical pesticides in pest management during storage against insects is often encouraged because synthetic insecticides produce multiple side-effects on human health and environment. Insecticidal activity of the hexane, dichloromethane, ethyl acetate and methanol extracts of bark of Trichilia gilgiana was tested on Sitophilus zeamaïs, Tribolium castaneum and Rhyzopertha dominica. The mortality rate was measured variable. The results of analysis showed that the mortality rate has a very highly significant variation following extracts, doses, insects and time considered $(P<0.001)$. Extracts with ethyl acetate and hexane of Trichilia gilgiana are effective against $S$. zeamais at the highest doses $(1 \mathrm{~g} / 10 \mathrm{~mL}$ and $0.5 \mathrm{~g} / 10 \mathrm{~mL}$ of solvent). These effective extracts were characterized by gas chromatography coupled with mass spectrometry. Molecules such as 2-Oxazalidone; thiocyanic acid; Methanethioamide, N,N-dimethyl; 2-Coumaranone and other were characterizated. These results may consolidate traditional use of Trichilia gilgiana in pest management.
\end{abstract}

Keywords: control, stored grains, indigenous plant, Trichilia gilgiana

\section{Introduction}

Several insects are involved in postharvest and storage, but beetles are also insects that cause not insignificant economic damage in postharvest (Delobel, 1993). Laboratory evaluation showed that when maize was unprotected, damages and losses due to Sitophilus zeamais (Motschulsky) reached 20\% and 40\%, respectively, in four and eight months of storage (Penning de Vries, 2001; Gueye et al., 2012). S. zeamaïs can also infest wheat, rice, barley, sorghum, millet, cassava, etc. (Delobel, 1993). One of the consequences of $S$. zeamaïs damage is the development of Aspergillus that secretes mycotoxins called aflatoxins and is the most powerful carcinogens known in humans as in animals (Abate et al., 2000; Coombs et al., 1997). T. castaneum can infest wheat, corn, barley, sorghum, millet, cassava, yams, peanuts, cotton, castor, cocoa, etc. (Delobel, 1993). R. dominica tackles a wide range of stored products, including cereals, wheat, barley, sorghum, rice, etc. (Delobel, 1993; CABI, 2010).

To control S. zeamaïs, T. castaneum and R. dominica, synthetic insecticides remains the primary means for controlling economical damage to crops, but this practice has come under scrutiny as it may pose potential oncogenic risks (Williams et al., 2012). However, S. zeamaïs, T. castaneum and R. dominica have developed resistance to insecticides from different chemical classes including organophosphates, carbamates, synthetic 
pyrethroids, and to some newer chemistry insecticides (Regnault-Roger et al., 2008; Ladang et al., 2008; Mahroof et al., 2010).

Bioinsecticidal control of postharvest insects, especially using indigenous plants, has been studied extensively and developed commercially as an alternative to chemical treatments.

Further, bioinsecticidal control is potentially safer and can have reduced impacts on the environment (Markussen. \& Kristensen, 2010). Inferences from indigenous traditional practices have uncovered plant chemicals that are useful in pest management, i.e., Nicotiana tabacum (Saxena, 1992), Pistacia lentiscus (Bachrouch et al., 2010), Boscia senegalensis (Gueye et al., 2013), Azadirachta indica (Taylor, 2005), Trichilia martiana (Saxena et al., 1992), Drypetes gossweileri (Aba- Toumnou et al., 2013), Afrostyrax lepidophyllus (Aba- Toumnou et al., 2014). In this context, an application of raw or extracts of plants may be a promising alternative for management of insect pests of crops.

Trichilia gilgiana is used in pest management of storage pests at Central African Republic (Lucie et al., 2012a). The objective of this study was to investigate insecticidal effects of extract of bark powder of $T$. gilgiana used by farmers in pest management in Central Africa Republic. Chemical investigate is made to characterize potential chemical compounds.

\section{Material and methods}

\subsection{Plant Material, Method of Extraction and Bioassays}

\subsubsection{Plant Material}

The bark of T. gilgiana was collected from Boukoko in Central African Republic in 2012 and authenticated by the researchers of the forestry Ministry of CAR and botanical Professors of University of Bangui (CAR) respectively. T. gilgiana bark was dried in the shade and grounder to powder after.

\subsubsection{Solvents and Method of Extraction}

- n-Hexan (Reag.USP, Ph.Eur.) PA-ACS; Mininum assay (G.C.) : 99,0\%; Identity : IR p/t.; Density at 20/20 : 0,659-0,663; Refractive index n $1,375-1,376$; Distillation range (>95\%dist.) : $67-69^{\circ} \mathrm{C}$;

- Dichloromethan stabilized with amylene PA-ACS-ISO; Mininum assay (G.C.) : 99,5\%; Identity : IR p/t.; Density at $20 / 4: 1,323-1,325$;

- Ethyl Acetate PA-ACS-ISO; Mininum assay (G.C.) : 99,5\%; Identity : IR p/t.; Density at 20/4 : 0,9000-0,902;

- Mathanol (Reag.USP, Ph.Eur.) PA-ACS-ISO; Mininum assay (G.C.): 99, 8\%; Identity: IR p/t.; Density at 20/4: $0,791-0,792$.

$100 \mathrm{~g}$ of powder of $T$. gilgiana has been dissolved in 500 milliliters of Hexan for 5 days in the laboratory. The final hexane extract was recovered after concentration on evaporator at $30^{\circ} \mathrm{C}$. The residue of hexane has been dried in air for 2 days and macerated in Dichloromethane. Similarly, the exhausted residue of Dichloromethane has been macerated in ethyl acetate whereas the spent residue in ethyl acetate has been macerated in methanol.

\subsubsection{Insects Rearing}

Adults of S. zeamaïs, T. castaneum and R. dominica were respectively collected from corn, millet and sorghum in farms and were reared respectively on $100 \mathrm{~g}$ of corn, millet and sorghum in laboratory at $27 \pm 2{ }^{\circ} \mathrm{C}$

\subsubsection{Bioassays}

Bioassays tests were conducted at the Regional Centre for Ecotoxicology Studies and Environment Security (CERES-Locustox) in Senegal, West Africa. The aim of bioassays was to identify effective extracts of $T$. gilgiana against $S$. zeamaïs, $T$. castaneum and $R$. dominica. Every extract has six doses $(1,0.5,0.25,0.125,0.62$ and 0.03 $\mathrm{g} / 10 \mathrm{~mL}$ of solvent) and every dose had been tested with five repetitions.

Theses doses were obtained by cascading dilution (Kéita et al., 2001). Experimental units were Petrie glass of 90 $\mathrm{cm}$ of diameter containing $20 \mathrm{~g}$ of grain (maize, millet or sorghum), infested with 25 insects and applied $1 \mathrm{~mL}$ of different doses. Insects are put in contact with treaded grains after having evaporated the solvent for 5 min from the hexane and dichloromethane extracts and $25 \mathrm{~min}$ from ethyl acetate and methanol extracts. Experimental units were randomly divided into four groups according to the treatments (Abbott, 1925). Insects groups of control were exposed to pure solvent in the same laboratory conditions at $27^{\circ} \mathrm{C} \pm 2{ }^{\circ} \mathrm{C}$ and $70 \% \pm 10 \%$ r.h.. Dead insects were removed using forceps every $5 \mathrm{~d}$ during $35 \mathrm{~d}$. Corrected mortality $(\mathrm{CM})$ is obtained by Abbott formula: $\mathrm{CM}=$ $[(\mathrm{TM}-\mathrm{CM}) /(100-\mathrm{CMt})] 100$ where, $\mathrm{TM}=$ treated mortality, $\mathrm{CM}$ = control mortality (Kéita et al., 2001; Abbott, 1925). 


\subsubsection{Statistical Analysis}

Corrected mortality is submitted to variance analysis, assigned model with four factors (plants, insects, doses and time) (Benelli et al., 2012). Mortality was transformed to $y=2 \arcsin (x / n) 0.5$ and emerged insects to $y=(x / n) 0.5$ ( $x=$ mortality rate, $n=$ size of population, $n=2519)$ to normalize the population and stabilize the variance. General linear model in Minitab 14 was used for statistical analysis.

\subsection{Chemistry Analysis}

\subsubsection{Materials and Conditions}

Silica Gel, spe 7086-06; colonne HP5MS: $30 \mathrm{~mm} 0.250 \mathrm{~mm}$ sur $0.25 \mu \mathrm{L}$; detector (190-400 nm); elution solvent: ethyle acetate; temperature: $325^{\circ} \mathrm{C}$; Gaz: Heluim; volume d'injection: $5 \mu \mathrm{L}$; GCMS 5973 Agilent.

\subsubsection{Method}

Gas chromatography coupled with a mass spectrometer was used in chemical characterization (Gohlke, 1993). 0.5 $\mathrm{g}$ of each extract was dissolved in $25 \mathrm{~mL}$ of the ethyl acetate or hexane. The mixture was purified with a silica column and then recovered and evaporated with rotavaporator. The concentrate was recovered with $2 \mathrm{~mL}$ of ethyl acetate in chromatographic tubes. $5 \mu \mathrm{L}$ of the extract was vaporized into an injection chamber in the column heading. The oven temperature program was initiated at $50^{\circ} \mathrm{C}$, held for $2 \mathrm{~min}$ then raised first at $100^{\circ} \mathrm{C}$, and raised in a second ramp at $3.5^{\circ} \mathrm{C} / \mathrm{min}$ to $300{ }^{\circ} \mathrm{C}$. Temperature influences the retention time, it allows to further separate the mixture of compounds. At the end of the column, the compounds are identified by an electron impact detector, coupled with a mass spectrometer. The mass spectral library and based Agilent 5973 GCMS data were used to characterize molecules.

\section{Results}

\subsection{Results of Bioassays Tests}

The results of analysis of variance (ANOVA) on the insecticidal effect of extracts of T. gilgiana against S. zeamais, $T$. castaneum and $R$. dominica showed that the mortality rate was a very highly significant variation according to the dose, the insect and the time on the one part and according to the plant, insect and dose on the other part $\quad(P$ $<0.001)$. Moreover it is only the effect of the interaction plant insects dose which was not significant $(P>0.05)$, and implies that the insecticidal effect depends on the nature of the plant, the dose and the insect (Table 1).

Table 1. Variance analysis of studied factors of Trichilia gilgiana

\begin{tabular}{|c|c|c|}
\hline \multirow[t]{2}{*}{ Factors/standard } & \multicolumn{2}{|c|}{ Standard of signification } \\
\hline & Effect on mortality & Effect on emerged insects \\
\hline Extracts/4 & $* * *$ & $* * *$ \\
\hline Doses/6 & $* * *$ & $* * *$ \\
\hline Insects/2 & $* * *$ & $* * *$ \\
\hline Times/7 & $* * *$ & 0. \\
\hline Extracts $\mathrm{x}$ doses $/ 24$ & 0. & $* *$ \\
\hline Extract $\mathrm{x}$ insects $/ 12$ & $* * *$ & $* * *$ \\
\hline Extracts $\mathrm{x}$ times $/ 28$ & $* * *$ & $* * *$ \\
\hline Doses $\mathrm{x}$ insects $/ 18$ & $* * *$ & $* *$ \\
\hline Doses $\mathrm{x}$ times $/ 42$ & $* * *$ & 0. \\
\hline Insects $\mathrm{x}$ times $/ 21$ & $* * *$ & $* * *$ \\
\hline Extracts $\mathrm{x}$ doses $\mathrm{x}$ insects $/ 72$ & $*$ & 0. \\
\hline Doses $\mathrm{x}$ insects $\mathrm{x}$ times/126 & $* * *$ & $* * *$ \\
\hline Extracts $\mathrm{x}$ insects $\mathrm{x}$ times $/ 84$ & $* *$ & 0. \\
\hline
\end{tabular}




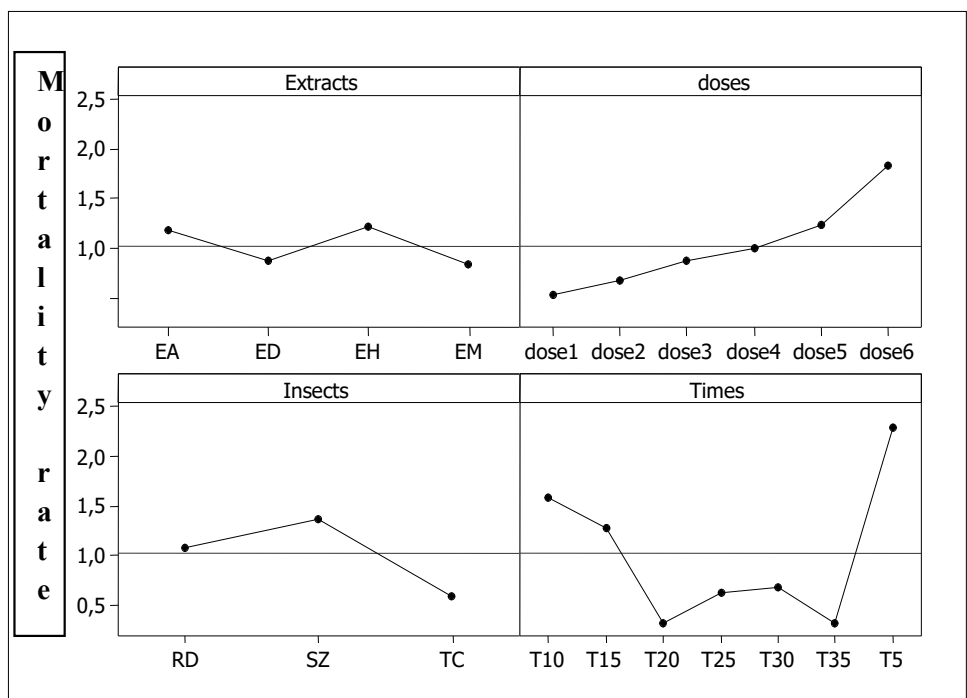

Figure 1. Main effects plot for rate of mortality with many extracts of Trichilia gilgiana

$\mathrm{EH}=$ hexane extract; $\mathrm{ED}=$ dichloromethane extract; $\mathrm{EA}=$ acetyl acetate extract; $\mathrm{EM}=$ methanol extract; $\mathrm{RD}=$ Rhyzopertha dominica; $\mathrm{SZ}=$ Sitophilus zeamaïs $\mathrm{TC}=$ Tribolium castaneum; $\mathrm{T} x=x$ days after treatment.

Figure 1 shows the evolution of treatment based extracts, dose, time and insects. Ethyl acetate and hexan extracts of $T$. gilgiana are effective against $S$. zeamais and $R$. dominica at high doses $(1 \mathrm{~g} / 10 \mathrm{~mL}$ and $0.5 \mathrm{~g} / 10 \mathrm{~mL}$ of solvent). The mortality curve over time shows that at $\mathrm{T} 5, \mathrm{~T} 10$ and $\mathrm{T} 15$, the mortality rate is high. It implies that the efficacy of the extracts with ethyl acetate and hexan is limited in time.

Table 2. Chemical characterization of hexane and ethyle acetate extracts of Trichilia gilgiana

\begin{tabular}{ll}
\hline$T R$ (min) & Chemical compounds \\
& Hexan extract of Trichilia gilgiana \\
1.201 & Methylene Chloride \\
1.750 & Methanethioamide, N, N-dimethyl; 2,3-Dihydrothiophene 1,1-dioxide \\
1.842 & 2-Oxazalidone; Thiocyanic acid, ethyl ester; 2-[2-[2(-Methoxyethoxy) ethoxyl et \\
& hoxyl] ethyl acetate \\
1.916 & Butane, 1-ethoxy- \\
2.076 & d-Glycer1-gluco-heptose; Octanoic acid, hexyl ester; 6-Desoxy-1-gulitol \\
2.379 & Octane ; Heptane, 2,4-dimethyl- \\
6.768 & Hexadecane; Decane, 2, 3,6-trimethyl-; Silane; trichlorooctadecyl- \\
7.054 & Decane, 2, 3,7-trimethyl-; Dodecane, 1-iodo-; Hexadecane, 2,6, 10,14-tetramethyl- \\
7.488 & Tetradecane \\
8.123 & Heneicosane ; Heptadecane ; Hexadecane \\
8.306 & Butylated Hydroxytoluene \\
8.426 & Dodecane ; Tridecane \\
8.500 & Dodecane ; 2-Bromo dodecane \\
8.569 & Hexadecane ; Tridecane ; Heneicosane \\
8.740 & 2-Bromotetradecane ; Heptadecane ; Hexadecane, 2, 6,10, 14-tetramethyl- \\
8.849 & Hexadecane \\
9.694 & Heptadecane \\
9.832 & Eicosane, 2-methyl- ; Heptacosane ; Heneicosane \\
10.077 & 2,6-Diisopropylnaphthalene ; 1-Acetyl-4, 6,8-trimethylazulene \\
10.134 & Naphthalene, 2-butyl-3-hexyl-1, 2, 3,4-tetrahydro- ; Naphthalene, 6-butyl-7-hexyl-1, 2, \\
& 3,4-tetrahydro- \\
& 6-Propyl-7H-benz [de] anthracen-7-on \\
\hline &
\end{tabular}




\begin{tabular}{ll}
\hline 10.249 & Heptadecane; Octadecane, 1-iodo-; Eicosane, 10-methyl- \\
10.489 & Tetratriacontane ; Pentadecane, 2, 6,10-trimethyl- ; Pentacosane \\
12.186 & Octacosane; Pentacosane; Tetratriacontane \\
12.289 & Octadecane; Silane, [1,4-phenylenebis (oxy)] bis [trimethyl-Heptadecane \\
12.724 & Pentacosane; Docosane; Octadecane, 2-methyl- \\
13.055 & Hexadecanoic acid, ethyl ester \\
15.678 & Octacosane ; Hentriacontane ; Heneicosane
\end{tabular}

Ethyle acetat extract of Trichilia gilgiana

1.213

1.739

1.807

2.007

3.625

5.962

6.265

6.528

6.734

7.043

7.128

7.248

7.363

7.494

7.523

7.580

7.688
Methylene Chloride

Methanethioamide, N, N-dimethyl; 2,3-Dihydrothiophene 1,1-dioxide

Formic acid hydrazide; Ethyne, chloro-; Thiirane

Hydrazine, 1,2-dimethyl-; Acetic acid; Thiirane

Dimethyl sulfone ; 1,4-Cyclohexadiene, 1-methyl-

Cyclotrisiloxane, hexamethyl- ; 1,2-Benzisothiazol-3-amine

Methysulfinyl; Disulfide, methyl; Methanamine, N-methoxy

2-Coumaranone; Benzeneacetic acid, 2-hydroxy-, methyl ester

3,3-Diisopropoxy-1, 1, 1, 5,5, 5- hexamethyltrisiloxane ; 7-Chloro-4-methoxy-3methylquinoline ; Propiophenone, 2-(trimethylsiloxy)-

2-Methoxy-4-vinylphenol ; Ethanone, 1-(3-methoxyphenyl)-

3,27-Dioxa-2,28-disilanonacosane, 2, 2,4, 28,28-pentamethyl-; Silane, ethenyldimethoxymethyl-3-Dimethylsilyloxy-6-ethyloctane

Dimethyl sulfoxide ; 5-Methoxybenzofurazan, 1-oxide

3-5-Dihydrotoluene ; 1,4-Benzenediol, 2-methyl-

Tetradecane ; Heptadecane, 8-methyl- ; Tetradecane

2H-1-Benzopyran-2-one, 3, 4-dihyro; 2(3H)-Benzofuranone, 3-methyl-

Benzaldehyde, 3-hydroxy-4-methoxy-; Vanillin

Cyclohexanone, 5-methyl-2-(1-methylethyl)-, (2R-cis); Cyclohexanone, 5-methyl-2(1-methylethyl)-, trans ; Cyclohexanone, 5-methyl-2-(1-methylethyl)-, cis

Naphthalene,1, 2,3,4,4a,5,6,8a-Octahydro-7-methyl-4-methyllene-1-(1-methylethyl)(1.alpha., 4a.alpha.,8a.alpha.)-; Cyclohexene, 6-ethenyl-6-methyl-1-(1-methyllethyl)3- (1-methylethylidene)-, (S)-

1,6-Cyclodecadiene, 1-methyl-5-methylene-8-(1-methyllethyl)-, [S-(E, E)]

Silane, methoxytripropyl-; Silane, ethoxytrimethyl-; Octadecanoic acid, 3-hydroxy-, methyl ester

Hexadecane ; Pentadecane

Phenol, 2,4-bis (1,1-dimethylethyl) ; Pentanoic acid, 5-hydroxy-, 2,4-di-t-butylphenyl esters

2-Propanone, 1-cyclopentyl-3-ethoxy-; 5-Amino-1-ethylpyrazole; Methanone, dicyclohexyl-

5, 5, 8a-Trimethyle-3, 4,6,7,8,8a-hexahydro-2H-chromene; 1,3-Benzenediol, 5-pentyl6-Methoxycoumaran-7-ol-3-one; Ethanone ; 1-(3,4-dimethoxyphenyl)-; Ethanone ; 1(2,5-dimethoxyphenyl)-

Fumaric acid, ethyl 2- fluorophenyl ester; 4-Amino-2,6-dihydroxypyrimidine; Isopropylphoshonic acid, fluoroanhydride, 4-methylcyclohexyl ester

6H-Purin-6-one, 2-amino-1,7-dihydro-; Thiazolo [5,4-d] pyrimidine, 5-methyl-; Benzaldehyde, 3-methoxy-, oxime

Phenol, 3, 4,5-trimethoxy; 1-1'-Biphenyl, 2-methoxy- 


\subsection{Results of Chemistry Analysis}

Chemical compounds were characterized using data base of Agilent database (5973) in the range of $50 \mathrm{~m} / \mathrm{z}$ to 550 $\mathrm{m} / \mathrm{z}$ (Figure 2). Hexane extract of $T$. gilgiana showed the presence of large peaks, additioned to other minor peaks. The signals for the main peak about 1.750 min (Figure 2) match the library mass spectra to 2-Oxazalidone and thiocyanic acid.

GC-MS profile of the Chemical compounds contained in ethyl acetat extract showed the presence of large peaks including other minor peaks. The signal for the peak about 1.739 min match to the library mass spectra to Methanethioamide, N,N-dimethyl (Figure 3).

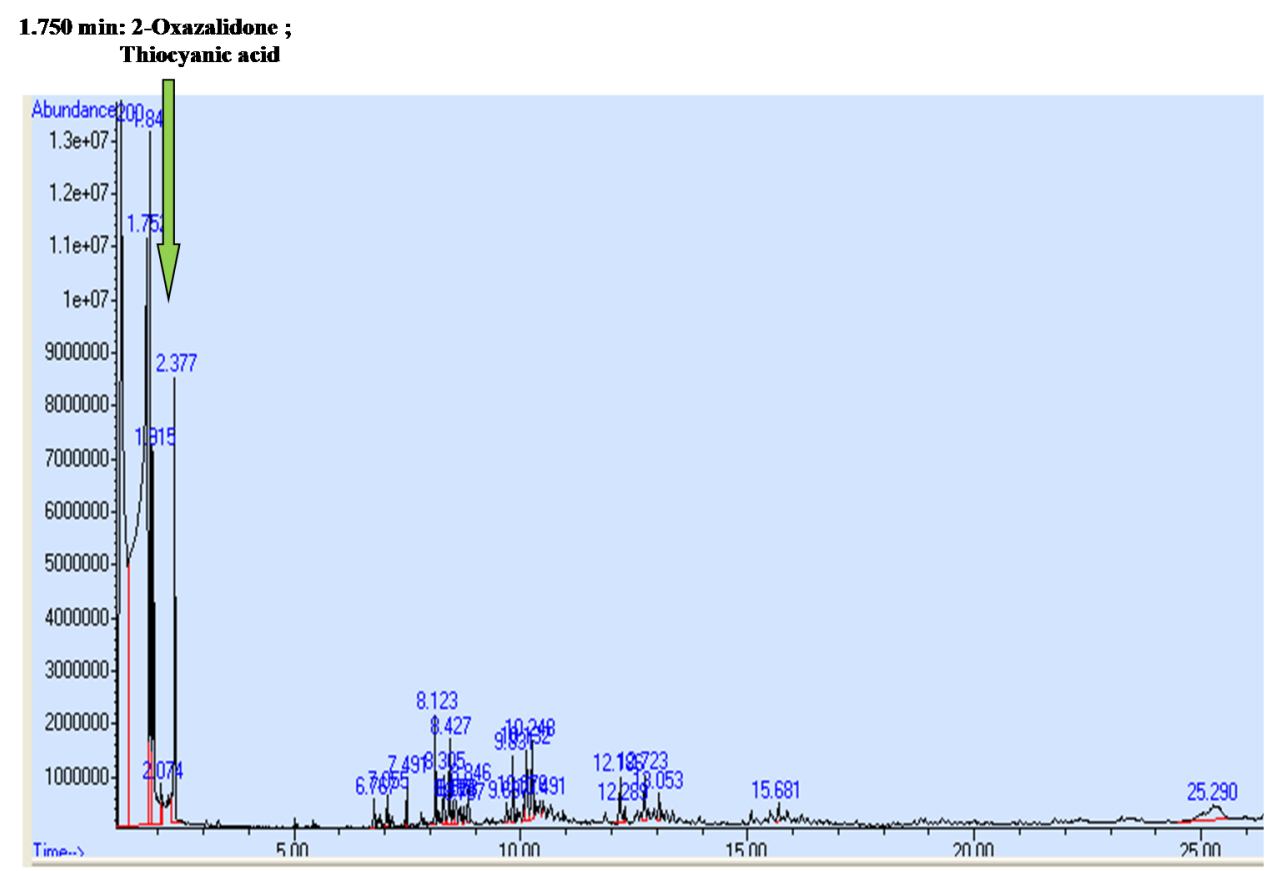

Figure 2. Chromatographic profile GC-MS of hexan extract of Trichilia gilgiana

1.739 min: Methanethioamide, N, N-dimethyl

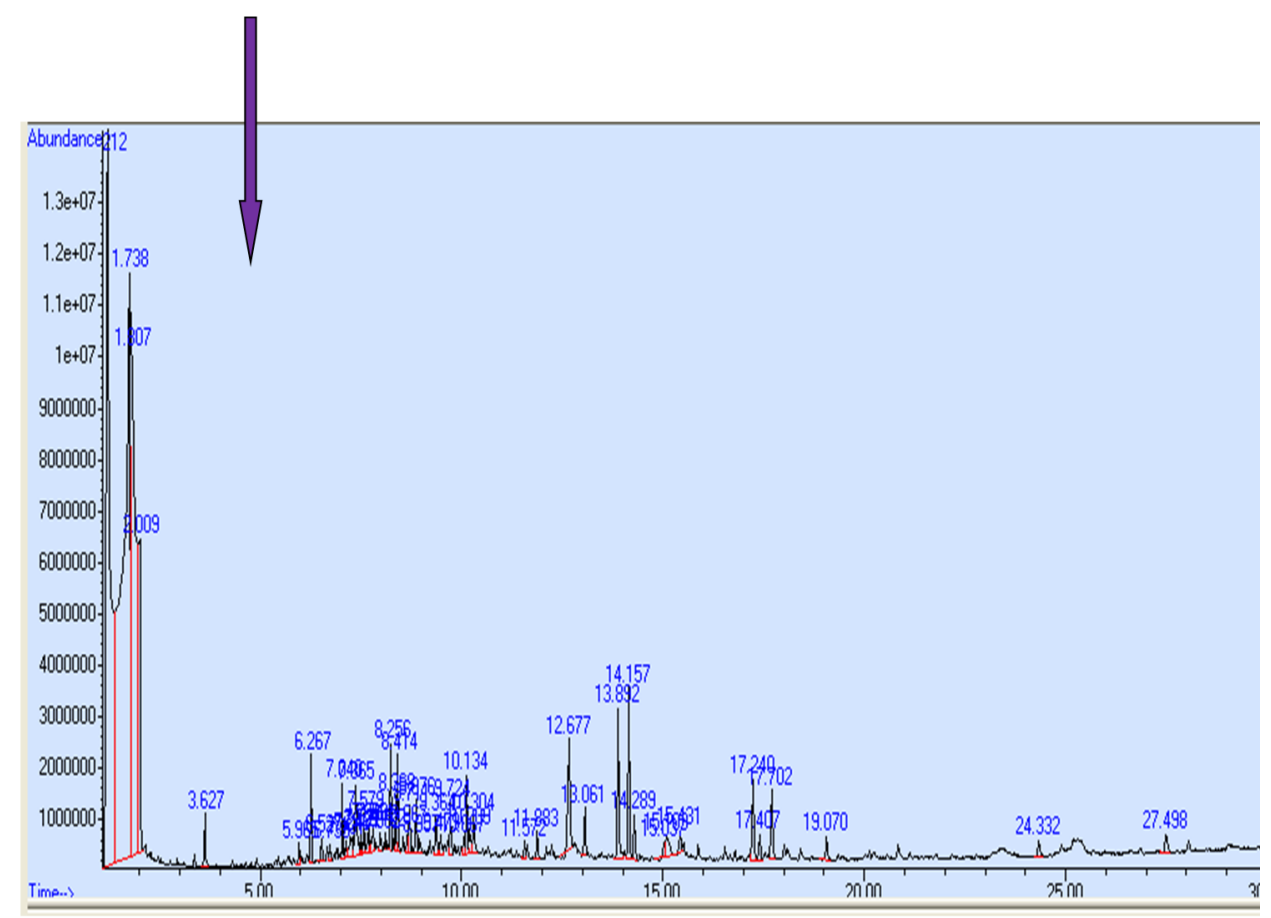

Figure 3. Chromatographic profile GC-MS of ethyl acetate extract of Trichilia gilgiana 


\section{Discussion}

Insecticidal activity of four extracts of T. gilgiana was tested on S. zeamais, T. castaneum and R. dominica. Hexan and ethyl acetate extracts of $T$. gilgiana are effective against $S$. zeamais. Previously, the authors have proved insecticidal activity of bark of $T$. gilgiana against $S$. zeamais and $T$. castaneum (Lucie et al., 2012b). Authors reported that powder of bark of T. gilgiana presented respectively on S. zeamais and T. castaneum the LC50 of $5.60 \mathrm{~g} / 100 \mathrm{~g}$ and $5.86 \mathrm{~g} / 100 \mathrm{~g}$ of corn or millet. Bioassays of hexan and ethyle acetate confirm preliminary insecticidal activity of $T$. gilgiana.

In general plants belonging to species families recognized for their pesticides action are widely used by farmers. The family of Meliaceae including 14 genuses (Lemmens, 2008) which one is Trichilia was largely counted. This family offers opportunities to isolate new compounds of insecticide property (Wheeler, 2000). The genus Trichilia mainly on the fruits of Trichilia martiana showed that this species contains two limonoids and a furan having an unsaturated chain c16 to c22 (Wheeler, 2000), similar to the structure of insecticidal compounds of avocado. Other studies (Satasook, 1992; Ewete et al., 1996b) on Asian Meliaceae have isolated the rocaglamide, a benzofuran having a comparable activity to that of azadirachtin, a natural insecticide.

Three families of secondary metabolites (alkaloids, tannins and terpenes) are often used by plants to defend themselves against external aggression (Regnault-Roger, 2008; Berenbaum, 1983; Feeny, 1976; Hagerman \& Butler, 1989).

Hexane extract reveals some molecules such as Thiocyanic acid, Methanethioamide, N, N-dimethyl, etc.

Thiocyanic acid and Methanethioamide, N, N-dimethyl are part of glucosinolates and are known for their involvement in the defense system of the plant against external aggression (Bodnaryk, 1991; Müller et al., 2001; Gueye, 2011).

The remaining molecule then quickly converts an Thiocyanic acid are the active substances that serve as defense for the plant (Smolinska, 2003; Gueye, 2011). Insecticidal activity of methyl isothiocyanate in Boscia senegalensis is proved on Caryedon serratus, S. zeamais, Prostephanus truncatus, Callosobruchus maculates and T. castaneum by enymatical degradation of glucocapparin in presence of water (Gueye, 2011). These results revealed the presence of chemical compounds belong to the group of glucosinolates. It is likely that the glucosinolates can play a key role in the insecticidal activity against $S$. zeamais in this study.

\section{Conclusions}

The objective of this study was to investigate insecticidal effects of extract of bark powder of $T$. gilgiana used by farmers in pest management in Central Africa Republic.The results of analysis showed that the mortality rate has a very highly significant variation following extracts, doses, insects and time considered $(P<0.001)$. Extracts with ethyl acetate and hexane of Trichilia gilgiana are effective against $S$. zeamais at the highest doses $(1 \mathrm{~g} / 10 \mathrm{~mL}$ and $0.5 \mathrm{~g} / 10 \mathrm{~mL}$ of solvent). These effective extracts (ethyl acetate and hexane) were characterized by gas chromatography coupled with mass spectrometry. Molecules such as 2-Oxazalidone; thiocyanic acid; Methanethioamide, N,N-dimethyl; 2-Coumaranone and other were characterizated in effective extracts (ethyl acetate and hexane ). These results may consolidate traditional use of Trichilia gilgiana in pest management.

\section{Acknowledgments}

This work was made possible through financial support of CERAAS (Regional Study Center for the Improvement of Adaptation to Drought) which helped the authors to carry out the surveys among farmers. The authors thank the Regional Centre for Ecotoxicology Studies and Environment Security (CERES-Locustox) including Central African Republic Institut of Agricultural Recherch (ICRA) for their logistic support. The authors show their sincere thanks to DAAD, too, (Deutscher Akademischer Austausch Dienst) for providing a PhD scholarship.

\section{References}

Lucie, A. T., Talla, G. M., Florent, B. O. S., Anna, T., Sabelle, G., Béranger, L. D. P., ... \& Mbacké, S. (2014). Pest Management of Storage Pests Using Extracts of Afrostyrax lepidophyllus against Sitophilus zeamaïs, Tribolium castaneum and Rhyzopertha dominica. Journal of Agricultural Science and Technology. B, 4(1B), 58.

Lucie, A. T., Dogo, S., Lakouetene, D. B., Florent, B. O., Talla, G. M., \& Anna, T. (2013). Chemical characterization and insecticidal activity of ethyl acetate and dichloromethane extracts of Drypetes gossweileri against Sitophilus zeamais, Tribolium castaneum and Rhyzopertha dominica. J Life Sci, 7(10), $1030-40$. 
Toumnou, L. A., Seck, D., Thiaw, C., Cisse, N., Kandioura, N., \& Sembene, M. Farmers' pesticidal plant use in the protection of stored cereal and legume grains: Ethnobotanical surveys in some rural communities in Senegal. International Journal of Science and Advanced Technology, 2(3), 25-33.

Abate, T., Van Huis, A., \& Ampofo, J. K. O. (2000). Pest management strategies in traditional agriculture: an African perspective. Annual review of entomology, 45(1), 631-659.

Toumnou, A. L., Seck, D., Namkosserena, S., Cisse, N., Kandioura, N., \& Sembene, M. (2012b). Utilisation des plantes indigènes à effet insecticide pour la protection des denrées stockées contre des insectes ravageurs à Boukoko (Centrafrique). International Journal of Biological and Chemical Sciences, 6(3), 1040-1050.

Abbott, W. S. (1925). A method of computing the effectiveness of an insecticide. J. of Economic Entomology, 18(2), 265-267.

Bachrouch, O., Mediouni-Ben Jemâa, J., Chaieb, I., Talou, T., Marzouk, B., \& Abderraba, M. (2010). Insecticidal activity of Pistacia lentiscus essential oil on Tribolium castaneum as alternative to chemical control in storage. Tunisian J. of Plant Protection, 5, 63-70.

Benelli, G., Flamini, G., Canale, A., \& Cioni, B. (2012). Toxicity of some essential oil formulations against the Mediterranean fruit fly Ceratitis capitata (Wiedemann) (Diptera Tephritidae). Crop Protection, 42, 223-229.

Berenbaum, M. (1983). Effects of tannin on growth and digestion in two species of Papilionids. Entomologia Experimentalis et Applicata, 34, 245-250.

Bodnaryk, R. P. (1991). Developmental profile of sinalbin (p-hydroxybenzyl glucosinolate) in mustard seedlings, Sinapsis alba L. and its relationship to insect resistance. J. Chem. Ecol., 17, 1543-1556.

CABI. (2010). Sitophilus zeamais (maize weevil) datasheet, Crop Protection Compendium, CABI International Publishing, Wallingford, UK. Retrieved from www.cabi.org/cpc

Coombs, C. W., Billings, C. J., \& Porter, J. E. (1977). The effect of yellow split-peas (Pisum sativum L.) and other pulses on the productivity of certain strains of Sitophilus oryzae (L.) (Col. Curculionidae) and the ability of other strains to breed thereon. J. of Stored Products Research, 13(2), 53-58.

Delobel, M. T. (1993). Foodstuff Beetles Stored in Hot Regions. ORSTOM, Paris, p. 424.

Ewete, F., Nicol, R. W., Hengsawad, V., Sukumalanand, P., Satasook, C., Wiriyachitra, P., ... \& Arnason, J. T. (1996). Insecticidal activity of Aglaia odorata extract and the active principle, rocaglamide, to the European corn borer, Ostrinia nubilalis Hübn.(Lep., Pyralidae). Journal of Applied Entomology, 120(1-5), 483-488.

Feeny, P. P. (1976). Plant apparency and chemical defense. Recent Advances in Phytochemistry, (10), 1-40.

Gohlke, R. S., \& McLafferty, F. W. (1993). Early gas chromatography/mass spectrometry. J. of the American Society for Mass Spectrometry, 4, 367-371.

Gueye, M. T., Seck, D., Ba, S., HELL, K., Sembene, M., \& Wathelet, J. P. (2012). Insecticidal activity of Boscia senegalensis (Pers.) Lam ex Poir. on Caryedon serratus (Ol.) pest of stored groundnuts. African J. of Agricultural Research, 6(30), 6348-6353.

Gueye, M.T., Seck, D., Ba, S., Hell, K., Sembène, M., \& Wathelet, J. P. (2011). Insecticidal activity of Boscia senegalensis on Caryedon serratus pest of stored groundnuts. African J. of Agricultural Research, 6(30), 6348-6353.

Gueye, M.T., Diallo, A., Diallo, Y., Seck, D., Vercammen, J., \& Lognay, G. (2013). Effects of MITC released from Boscia Senegalensis as biopesticide in Senegalese seeds with special attention to cowpea: Detection of residues. J. of Environment and Ecology, 4(1), 29-39.

Hagerman, A. E., \& Butler, L. G. (1989). Choosing appropriate methods and standards for assaying tannin. Journal of Chemical Ecology, (15), 1795- 1810.

Kéita, S. M., Schmit, V. C., Ramaswamy, J., \& Bélanger, S. A. (2001). Effect of various essential oils on Callosobruchus maculatus (F.) (Coleoptera, Bruchidae). J. Stor. Prod. Res., 36, 349-355.

Ladang, Y. D., Ngamo, L. T. S., Ngassoum, M. B., Mapongmestsem, P. M., \& Hance, T. (2008). Effect of sorghum cultivars on population growth and grain damages by the rice weevil, Sitophilus oryzae L. (Coleoptera: Curculionidae). African J. of Agricultural Research, 3(2), 255-258.

Lemmens, R. H. M. J. (2008). Trichilia gilgiana Harms. In D. Louppe, A. A. Oteng-Amoako, \& M. Brink (Eds.), Prota 7(1): Timbers/Bois d'œuvre 1. PROTA, Wageningen, Netherlands. 
Mahroof, R. M., Edde, P. A., Robertson, B., Puckette, J. A., \& Phillips, T. W. (2010). Dispersal of Rhyzopertha dominica (Coleoptera: Bostrichidae) in different habitats. Environ Entomol, 39(3), 930-938.

Markussen, M. D. K., \& Kristensen, M. (2010). Low expression of nicotinic acetylcholine receptor subunit Mda2 in neonicotinoid-resistant strains of Musca domestica L.. Pest Manag. Sci., 66, 1257-1263.

Müller, C., Agerbirk, N., Olsen, C. E., Boevé, J. L., \& Schaffner, P. M. (2001). Brakefield, Sequestration of host plant glucosinolates in the defensive hemolymph of the sawfly Athalia rosae. J. of Chemical Ecology, 27(12), 2505-2516.

Penning de Vries, F. W. T. (2001). Food security? We are losing ground fast. In J. Noesberger, H. H. Geiger, \& P. C. Struik (Eds.), Crop Science: Progress and Prospects (pp. 1-14).

Regnault-Roger, C., Philogène, B. J. R., \& Vincent, C. (2008). Biopesticides d'origine végétale (2nd ed.). Lavoisier, Paris. édition, 550p.

Satasook, C., Isma, M. B., \& Wiriyachitra, P. (1992). Activity of rocaglamide, an insecticidal naturel product, againt the variegated cutworm, Peridroma saucia (Lepidoptera: Noctuidae). Pesticide Science, 36, 53-58.

Saxena, R. C., Dixit, O. P., \& Harshan, V. (1992). Insecticidal action of Lantana camara against Callosobruchus chinensis (Coleoptera: Bruchidae). J. Stored Prod. Res., 28, 279-281.

Smolinska, U., Morra, M. J., Knudsen, G. R., \& James, R. L. (2003). Isothiocyanates produced by Brassicaceae species as inhibitors of Fusarium oxysporum. Plant Dis., 87, 407-412.

Taylor, L. (2005). The healing power of rainforest herbs, 2005. Retrieved Dec. 21, 2009, from www.raintree.com/quinine.

Wheeler, D. A. (2000). The effet of Trichilia Americana extract on the growth development and behavior of the Asian army worm, Spodoptera litura. PhD. Thesis, University of British Columbia, 210p.

Williams, P. J., Geladi, P., Britz, T. J., \& Manley, M. (2012). Investigation of fungal development in maize kernels using NIR hyperspectral imaging and multivariate data analysis. J. of Cereal Science, 55, 272-278.

\section{Copyrights}

Copyright for this article is retained by the author(s), with first publication rights granted to the journal.

This is an open-access article distributed under the terms and conditions of the Creative Commons Attribution license (http://creativecommons.org/licenses/by/3.0/). 